\title{
Differential pharmacology and clinical utility of long-acting bronchodilators in COPD - focus on olodaterol
}

This article was published in the following Dove Press journal:

Therapeutics and Clinical Risk Management

4 December 2015

Number of times this article has been viewed

\author{
Maria Gabriella Matera' \\ Josuel Ora² \\ Mario Cazzola ${ }^{2,3}$ \\ 'Department of Experimental \\ Medicine, Unit of Pharmacology, \\ Second University of Naples, Naples, \\ ${ }^{2}$ Division of Respiratory Medicine, \\ University Hospital Tor Vergata, \\ ${ }^{3}$ Department of Systems Medicine, \\ Respiratory Pharmacology Research \\ Unit, University of Rome Tor Vergata, \\ Rome, Italy
}

\begin{abstract}
Olodaterol (BI $1744 \mathrm{CL}$ ) is a novel, once-daily long-acting $\beta_{2}$-agonist (LABA) designed with the aim of improving $\beta_{2}$-adrenoreceptor selectivity and intrinsic activity. Phase III pivotal trials have documented that olodaterol Respimat Soft Mist inhaler $5 \mu \mathrm{g}$ induces fast onset of bronchodilation, comparable with formoterol at day 1 . Moreover, significant lung function improvements have been documented up to 48 weeks in patients with moderate to very severe chronic obstructive pulmonary disease (COPD). Olodaterol was generally well tolerated and had an acceptable cardiovascular and respiratory adverse event profile. Regrettably, the clinical development of olodaterol is however still too partial to draw any firm conclusions on the positioning of this ultra-LABA as monotherapy in the management of COPD. Waiting for further data on the impact of olodaterol on different patient-reported outcomes, which however are widely available for indacaterol, and mainly for a head-to-head comparison between these two ultra-LABAs and between olodaterol long-acting antimuscarinic antagonists other than tiotropium, we believe it is correct to follow the clinical indications of indacaterol also for olodaterol. In any case, the parallel bronchodilating modes of action of olodaterol and tiotropium make them an attractive combination in COPD. The results from the ongoing large TOviTO Phase III trial program have documented the efficacy and safety of olodaterol/tiotropium fixeddose combination as maintenance therapy in patients with moderate to very severe COPD. In particular, olodaterol/tiotropium fixed-dose combination provides a convincing alternative for patients remaining symptomatic with olodaterol monotherapy.
\end{abstract}

Keywords: olodaterol, $\beta_{2}$-agonists, once-daily dose, chronic obstructive pulmonary disease

\section{Introduction}

Bronchodilators are central to the treatment of chronic obstructive pulmonary disease (COPD) at all stages of the disease even when there is often limited reversibility of airflow obstruction ${ }^{1}$ because they can influence airflow limitation and, consequently, diminish pulmonary hyperinflation, and improve emptying of the lung and exercise performance. Unfortunately, there is still no sufficient evidence to use bronchodilator treatment in asymptomatic COPD patients. $^{2}$

Three classes of bronchodilators, namely $\beta_{2}$-agonists, antimuscarinic agents, and methylxanthines, are currently available. For both $\beta_{2}$-agonists and antimuscarinic agents, long-acting formulations are preferred over short-acting formulations. ${ }^{3}$ Generally, guidelines do not indicate which class of bronchodilators should be used as the first choice, ${ }^{2-4}$ likely because there is no solid clinical proof to support one treatment over another. Physicians often start treatment with an empiric choice, evaluating the clinical response to therapy. However, there is evidence that long-acting $\beta_{2}$-agonists
Correspondence: Mario Cazzola Department of Systems Medicine, Respiratory Pharmacology Research Unit, University of Rome Tor Vergata, Via Montpellier I, 00I33 Rome, Italy Email mario.cazzola@uniroma2.it
Therapeutics and Clinical Risk Management 2015:I I 1805-18II 1805

Dovepress

http://dx.doi.org/10.2147/TCRM.S7358 I (c) (i) (2) 2015 Matera et al. This work is published by Dove Medical Press Limited, and licensed under Creative Commons Attribution - Non Commercial (unported, v3.0) BY LC License. The full terms of the License are available at http://creativecommons.org/licenses/by-nc/3.0/. Non-commercial uses of the work are permitted without any further permission from Dove Medical Press Limited, provided the work is properly attributed. Permissions beyond the scope of the License are administered by Dove Medical Press Limited. Information on how to request permission may be found at: http://www.dovepress.com/permissions.php 
(LABAs) are more effective than long-acting antimuscarinic antagonists (LAMAs) if symptoms or health-related quality of life (HRQoL) are considered the primary outcomes, whereas the use of a LAMA seems preferable in frequent exacerbators. $^{5}$

\section{Pharmacology, mode of action, pharmacokinetics}

Olodaterol (BI 1744 CL) is a novel once-daily LABA designed with the aim of improving $\beta_{2}$-adrenoreceptor (AR) selectivity and intrinsic activity. The fact that the $\beta_{2}$-AR selectivity improves if the phenolic hydroxyl group of the $\beta_{2}$-agonist is shifted from the para- to the meta-position with respect to the ethanolamine substituent has long been known. ${ }^{6}$ Terbutaline is a noticeable selective $\beta_{2}$-agonist with a phenolic hydroxyl group in the meta-position. Driven by this hypothesis, a series of 6-hydroxy-4H-benzo[1,4] oxazin-3-ones was investigated. One compound, $(R)-4 \mathrm{p}$ (olodaterol) showed a long duration of action ( 24 hours) in two preclinical in vivo models of bronchoprotection and a superior safety margin compared to formoterol. ${ }^{7}$

Olodaterol is structurally distinct from formoterol and salmeterol and is enantiomeric pure. This is a critical property. All $\beta$-agonists are racemates, or drugs composed of two nonsuperimposable mirror image molecules in accordance to their molecular configuration. ${ }^{8}$ Generally, the $(R)$ enantiomer is the active component and the $(S)$-enantiomer is inactive in therapeutic concentrations. ${ }^{9}$ In vitro studies of the racemic mixture and purified isomers support a role for the $(S)$-enantiomer in inducing tachyphylaxis or receptor desensitization. ${ }^{10}$ Accordingly, pure $(R, R)$ - $\beta$-agonists provide bronchodilation at lower doses than the racemate, allowing for fewer $\beta_{2}$-AR-mediated side effects.

Olodaterol has a near full-agonist profile at human (h) $\beta_{2}$-AR. In contrast with formoterol, olodaterol is only a partial agonist at $\mathrm{h} \beta_{1}-\mathrm{AR}$ and shows an increased functional selectivity versus the $\beta_{1}$ - and $\beta_{3}$-ARs. ${ }^{11}$ Olodaterol effectively reversed contraction induced by different stimuli in isolated human bronchi with non-significant differences in potency and efficacy when compared with formoterol. Studies with precision-cut lung slices obtained from rat lungs and human lung tissue showed that olodaterol is comparable with formoterol and displayed significantly increased relaxation after partial precontraction of human small airways in response to carbachol. ${ }^{12}$ The binding, kinetic, and functional properties of olodaterol show that the drug forms a stable complex with the $\beta_{2}$-AR. ${ }^{13}$ More specifically, olodaterol has a biphasic dissociation profile from human $\beta_{2}$-ARs, the fast component with a half-life of 32 minutes and the slow component (about $30 \%-40 \%$ of the total $\beta_{2}$-AR pool) showing a half-life of dissociation of 17.8 hours, providing a rationale for a long duration of action. In fact, in vivo antagonistic effects of single doses of olodaterol and formoterol were measured against ACh challenges in anesthetized guinea pigs and dogs for up to 24 hours by using the Respimat Soft Mist inhaler (SMI, Boehringer Ingelheim Pharmaceuticals, Inc., Ridgefield, CT, USA). In both models, olodaterol provided bronchoprotection over 24 hours, whereas formoterol used at an equally effective dose was unable to maintain efficacy over 24 hours. In both models, the onset of action of olodaterol was as fast as that of formoterol.

With regard to the mechanistic rationale for the observed long duration of action of olodaterol in vivo, it has been documented that olodaterol has a moderate propensity to accumulate in the lipid bilayer, and therefore the microkinetic theory cannot be fully dismissed. ${ }^{13}$ However, a second aspect, namely, the tight binding of olodaterol to the human $\beta_{2}$-AR and formation of the ternary complex, was identified. ${ }^{13}$

The pharmacokinetics of inhaled olodaterol are linear across once-daily doses of $2-40 \mu \mathrm{g}$, although in most COPD patients no plasma levels were detected following the $2 \mu \mathrm{g}$ dose and maximum concentration $\left(C_{\max }\right)$ was reached within 10 minutes after administration. ${ }^{14}$ Olodaterol plasma concentrations declined quickly and represented $37 \%-56 \%$ of $C_{\max }$ at 6 hours on regular treatment following inhalation of 10 and $20 \mu \mathrm{g}$ olodaterol. ${ }^{15}$ Trough plasma concentrations were mostly below the limit of quantification $(2.0 \mathrm{pg} / \mathrm{mL})$ following inhalation olodaterol $5 \mu \mathrm{g}$ once daily and were quantifiable in more than one-third of patients after olodaterol $5 \mu \mathrm{g}$ twice daily and $10 \mu \mathrm{g}$ once daily. ${ }^{15}$ Systemic exposure parameters of olodaterol, steady-state $C_{\max }$, and steady-state area under the curve (AUC) from 0 to 1 hour increased proportionally within the $5-20 \mu \mathrm{g}$ dose range. ${ }^{14}$ The fraction of dose excreted through the kidneys within the dosing interval was similar across all dose groups. ${ }^{15}$

\section{Efficacy studies Phase II studies}

In an initial Phase II study, 36 patients with moderate to very severe COPD were randomly assigned to inhale a single dose of placebo or olodaterol 2, 5, 10, or $20 \mu \mathrm{g}$ delivered as an aqueous solution via Respimat SMI (Boehringer Ingelheim Pharmaceuticals, Inc., Ingelheim, Germany). ${ }^{14}$ All doses of olodaterol provided significantly greater bronchodilation compared to placebo in 24-hour forced expiratory volume in 1 second $\left(\mathrm{FEV}_{1}\right)$ postdose, but dose response was most 
pronounced with the two lower doses and started to plateau with the two higher doses. Improvements in forced vital capacity (FVC) closely reflected the $\mathrm{FEV}_{1}$ results.

A second Phase II study with a randomized, double-blind, four-way crossover design, in which 47 COPD patients inhaled olodaterol once daily ( 5 or $10 \mu \mathrm{g}$ ) or twice daily ( 2 or $5 \mu \mathrm{g}$ two times a day) for 3 weeks, showed that olodaterol 5 and $10 \mu \mathrm{g}$ administered once daily provided significant and identical bronchodilation over a complete 24-hour period. ${ }^{16}$ Olodaterol $5 \mu \mathrm{g}$ administered once daily had a better 24-hour profile compared with olodaterol $2 \mu \mathrm{g}$ twice daily and a similar degree of bronchodilation over 24 hours compared with double the daily dose administered as either a once-daily $(10 \mu \mathrm{g})$ or twice-daily $(5 \mu \mathrm{g})$ dosing regimen. There was no evidence of carry-over effect with twice-daily dosing compared to once-daily dosing, as assessed by efficacy of twice-daily olodaterol $5 \mu \mathrm{g}$ versus once-daily olodaterol $5 \mu \mathrm{g}$ during the 0 - to 12 -hour period following the morning dose. This study offered robust support for the development of olodaterol $5 \mu \mathrm{g}$ once daily in COPD.

In another Phase II study, 405 patients with moderate to very severe COPD were randomly assigned to 4 weeks of double-blind treatment, in which they received an inhalation solution containing one of four olodaterol doses $(2,5$, 10 , or $20 \mu \mathrm{g}$ ), or placebo, delivered by the Respimat SMI (Boehringer Ingelheim Pharmaceuticals, Inc.). ${ }^{15} \mathrm{~A}$ clear dose-response relationship was observed with respect to pulmonary function for the tested dose range with no further increase in efficacy observed with $20 \mu \mathrm{g}$ compared to $10 \mu \mathrm{g}$ and improvements in FVC supported those observed for $\mathrm{FEV}_{1}$.

The results of these Phase II studies (Table 1) provided the rationale to further investigate 5 and $10 \mu \mathrm{g}$ once-daily doses of olodaterol in a Phase III clinical program.

\section{Phase III pivotal trials}

Four papers, each reporting two replicative studies, have described the Phase III pivotal trials (Table 2).

In two replicate, randomized, double-blind, placebocontrolled, parallel-group, Phase III pivotal trials, 1,266 patients with moderate to very severe COPD were randomized to receive olodaterol 5 or $10 \mu \mathrm{g}$ once daily or placebo; randomization was stratified based on concomitant tiotropium use to ensure balanced assignment across treatment arms. ${ }^{17}$ The treatment period was 48 weeks, with a final follow-up 2 weeks later. However, primary efficacy evaluations were carried out at 12 weeks, in line with US Food and Drug Administration requirement. In both studies, olodaterol 5 and $10 \mu \mathrm{g}$ significantly improved the $\mathrm{FEV}_{1} \mathrm{AUC}_{0-3}$ response and trough $\mathrm{FEV}_{1}$ at week 12 , with no statistically significant differences between olodaterol 5 and $10 \mu \mathrm{g}$ in either coprimary end points. These improvements were also evident at weeks 24 and 48. Interestingly, improvements in $\mathrm{FEV}_{1}$ with olodaterol were evident from 5 minutes after the first dose. Once again, improvements

Table I Phase II pivotal studies

\begin{tabular}{|c|c|c|c|c|}
\hline Study & Design & No of patients & Treatments & Results \\
\hline van Noord et al ${ }^{14}$ & $\begin{array}{l}\text { Single-center, double-blind, } \\
\text { placebo-controlled, five-way } \\
\text { crossover study }\end{array}$ & 36 & $\begin{array}{l}\text { Olodaterol SMI } 2,5 \text {, } \\
10, \text { or } 20 \mu \mathrm{g}\end{array}$ & $\begin{array}{l}\text { All olodaterol doses superior to placebo for } \\
\text { trough } F E V_{1} \text {, peak } F E V_{1}(0.12 \mathrm{I}-0.2 \mathrm{I} \mathrm{L}) \text {, and } \\
\text { average } \mathrm{FEV} \text {, both during the daytime }(0-12 \mathrm{~h} \text {; } \\
\text { ranging from } 0.099 \text { to } 0.184 \mathrm{~L}) \text { and nighttime } \\
(\mathrm{I} 2-24 \mathrm{~h} \text {; ranging from } 0.074 \text { to } 0.14 \mathrm{I} \mathrm{L})\end{array}$ \\
\hline Maleki-Yazdi et al ${ }^{15}$ & $\begin{array}{l}\text { Multicenter, randomized, } \\
\text { double-blind, placebo- } \\
\text { controlled, parallel-group, } \\
\text { dose-finding study }\end{array}$ & 405 & $\begin{array}{l}\text { Olodaterol SMI } 2 \text {, } \\
5,10, \text { or } 20 \mu \mathrm{g} \text { QD } \\
\text { for } 4 \text { weeks }\end{array}$ & $\begin{array}{l}\text { All olodaterol doses superior to placebo for } \\
\text { trough FEV, versus placebo }(2 \mu \mathrm{g}, 0.06 \mathrm{I} \mathrm{L} \text {; } \\
5 \mu \mathrm{g}, 0.097 \mathrm{~L} ; 10 \mu \mathrm{g}, 0.123 \mathrm{~L} ; 20 \mu \mathrm{g}, 0.132 \mathrm{~L}) \\
\text { The two highest doses ( } 10 \text { and } 20 \mu \mathrm{g}) \text { formed } \\
\text { the plateau of the dose-response curve }\end{array}$ \\
\hline Joos et al ${ }^{16}$ & $\begin{array}{l}\text { Randomized, double-blind, } \\
\text { four-way, crossover, study }\end{array}$ & 47 & $\begin{array}{l}\text { Olodaterol SMI } 2 \mu \mathrm{g} \\
\text { BID, } 5 \mu \mathrm{g} \text { BID, } 5 \mu \mathrm{g} \\
\text { QD, and I0 } \mu \mathrm{g} \text { QD } \\
\text { for } 3 \text { weeks }\end{array}$ & 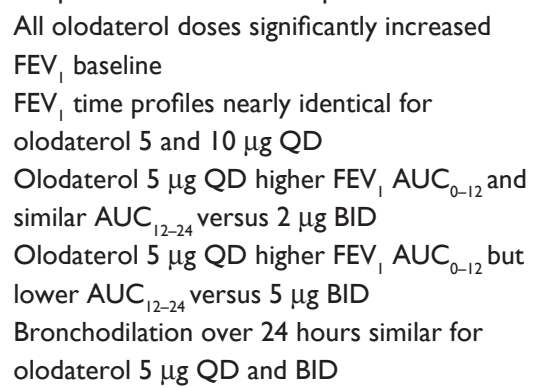 \\
\hline
\end{tabular}

Abbreviations: $\mathrm{QD}$, once daily; BID, twice daily; $\mathrm{FEV}_{1}$, forced expiratory volume in I second; $\mathrm{AUC} \mathrm{C}_{0-12}$, area under the curve from 0 to 12 hours; $\mathrm{AUC} \mathrm{C}_{12-24}$, area under the curve from 12 to 24 hours; SMI, Soft Mist inhaler; h, hour. 
Table 2 Phase III pivotal studies

\begin{tabular}{|c|c|c|c|c|}
\hline Study & Design & No of patients & Treatments & Results \\
\hline Ferguson et al ${ }^{17}$ & $\begin{array}{l}\text { Two replicate, randomized, } \\
\text { double-blind, placebo- } \\
\text { controlled, parallel-group, } \\
\text { trials }\end{array}$ & $\mathrm{I}, 266(624+642)$ & $\begin{array}{l}\text { Olodaterol SMI } 5 \\
\text { or } 10 \mu \mathrm{g} \text { QD for } \\
48 \text { weeks }\end{array}$ & $\begin{array}{l}\text { Significant improvement in } \mathrm{FEV}, \mathrm{AUC}_{0-3} \text { and } \\
\text { trough } \mathrm{FEV} \text {, at week } 12(5 \mu \mathrm{g}, 0.172 \text { and } 0.176 \mathrm{~L} \text {; } \\
\mathrm{I} 0 \mu \mathrm{g}, 0.09 \mathrm{I} \text { and } 0.10 \mathrm{I} \mathrm{L}) \text { and week } 48(5 \mu \mathrm{g}, \\
0.173 \text { and } 0.169 \mathrm{~L} ; 10 \mu \mathrm{g}, 0.092 \text { and } 0.09 \mathrm{I} \mathrm{L}) \\
\text { Daytime rescue medication use reduced for } \\
\text { both olodaterol doses }(5 \mu \mathrm{g},-0.46 ; 10 \mu \mathrm{g},-0.57 \\
\text { actuations/day) } \\
\text { Nighttime rescue medication use reduced for } \\
\text { both olodaterol doses }(5 \mu \mathrm{g},-0.50 ; 10 \mu \mathrm{g},-0.78 \\
\text { actuations/day) } \\
\text { PGR scores, statistically significantly improved } \\
\text { versus placebo with both olodaterol doses }\end{array}$ \\
\hline Koch et $\mathrm{al}^{18}$ & $\begin{array}{l}\text { Two replicate, randomized, } \\
\text { double-blind, placebo- } \\
\text { controlled, parallel-group, } \\
\text { trials }\end{array}$ & I,838 (904+934) & $\begin{array}{l}\text { Olodaterol SMI } 5 \\
\text { and } 10 \mu \mathrm{g} \text { QD and } \\
\text { formoterol I } 2 \mu \mathrm{g} \text { BID } \\
\text { for } 48 \text { weeks }\end{array}$ & $\begin{array}{l}\text { In both trials at week } 24 \text {, significant } \\
\text { improvement in } \mathrm{FEV}, \mathrm{AUC}_{0-3}(5 \mu \mathrm{g}, 0.15 \mathrm{I} \text { and } \\
0.129 \mathrm{~L} ; 10 \mu \mathrm{g}, 0.165 \text { and } 0.154 \mathrm{~L} \text {; formoterol, } \\
0.177 \text { and } 0.150 \mathrm{~L}) \text { and trough } \mathrm{FEV},(5 \mu \mathrm{g} \text {, } \\
0.078 \text { and } 0.053 \mathrm{~L} ; 10 \mu \mathrm{g}, 0.085 \text { and } 0.069 \mathrm{~L} \text {; } \\
\text { formoterol, } 0.054 \text { and } 0.042 \mathrm{~L}) \text { versus placebo } \\
\text { No statistically significant differences in TDI } \\
\text { focal score for any of the active therapies versus } \\
\text { placebo at week } 24 \\
\text { Improvement in SGRQ total score for } 5 \mu \mathrm{g} \\
(-2.8) \text { and } 10 \mu \mathrm{g}(-3.4) \text {, but not formoterol } \\
(-1.2) \text { compared to placebo at week } 24 \\
\text { Significant reductions in weekly mean daytime } \\
\text { and nighttime rescue medication compared to } \\
\text { placebo throughout the } 48 \text {-week treatment } \\
\text { period }\end{array}$ \\
\hline Feldman et al ${ }^{19}$ & $\begin{array}{l}\text { Two replicate, multicenter, } \\
\text { randomized, double-blind, } \\
\text { double-dummy, placebo- } \\
\text { controlled, four-way } \\
\text { crossover studies }\end{array}$ & $199(99+100)$ & $\begin{array}{l}\text { Olodaterol SMI } 5 \text { and } \\
10 \mu \mathrm{g} \text { QD and } \\
\text { formoterol } 12 \mu \mathrm{g} \\
\text { BID for } 6 \text { weeks in } \\
\text { addition to usual- } \\
\text { care background } \\
\text { maintenance therapy }\end{array}$ & $\begin{array}{l}\text { No differences between } 5 \text { and } 10 \mu \mathrm{g} \text { for the } \\
\mathrm{FEV}, \mathrm{AUC}_{0-12} \text { and } \mathrm{FEV}, \mathrm{AUC}_{12-24} \text { response } \\
\text { No differences between } 5 \text { and } 10 \mu \mathrm{g} \text { compared } \\
\text { to formoterol for the } \mathrm{FEV}, \mathrm{AUC}_{0-12} \text { response } \\
\text { and } \mathrm{FEV}, \mathrm{AUC}_{12-24} \text { response for formoterol } \\
\text { greater than } 5 \text { and } 10 \mu \mathrm{g} \\
\text { No differences in peak FEV, responses between } \\
5 \text { and } 10 \mu \mathrm{g} \text {, but peak FEV, response for both } 5 \\
\text { and } 10 \mu \mathrm{g} \text { lower than formoterol (- } 0.036 \text { and } \\
-0.034 \mathrm{~L} \text {, respectively) }\end{array}$ \\
\hline Lange et $\mathrm{al}^{20}$ & $\begin{array}{l}\text { Two replicate, randomized, } \\
\text { double-blind, four-way } \\
\text { crossover, active- and } \\
\text { placebo-controlled trials }\end{array}$ & $230(108+122)$ & $\begin{array}{l}\text { Olodaterol SMI } 5 \\
\text { and I0 } \mu \mathrm{g} \text { QD and } \\
\text { tiotropium I } 8 \mu \mathrm{g} \text { QD } \\
\text { via the HandiHaler for } \\
6 \text { weeks }\end{array}$ & $\begin{array}{l}\text { In both trials at week } 6 \text {, significant improvement } \\
\text { in } \mathrm{FEV}, \mathrm{AUC}_{0-3}(5 \mu \mathrm{g}, 0.206 \text { and } 0.214 \mathrm{~L} ; 10 \mu \mathrm{g} \text {, } \\
0.215 \text { and } 0.245 \mathrm{~L} \text {; tiotropium, } 0.182 \text { and } \\
0.235 \mathrm{~L}), \mathrm{FEV}, \mathrm{AUC}_{0-12}(5 \mu \mathrm{g}, 0.185 \text { and } 0.197 \mathrm{~L} \text {; } \\
10 \mu \mathrm{g}, 0.207 \text { and } 0.197 \mathrm{~L} \text {; tiotropium, } 0.173 \text { and } \\
0.22 \mathrm{~L}), \mathrm{FEV}_{1} \mathrm{AUC}_{12-24}(5 \mu \mathrm{g}, 0.13 \mathrm{I} \text { and } 0.153 \mathrm{~L} \text {; } \\
10 \mu \mathrm{g}, 0.178 \text { and } 0.170 \mathrm{~L} \text {; tiotropium, } 0.123 \\
\text { and } 0.164 \mathrm{~L}) \text {, and trough } \mathrm{FEV},(5 \mu \mathrm{g}, 0.133 \text { and } \\
0.134 \mathrm{~L} ; 10 \mu \mathrm{g}, 0.147 \text { and } 0.143 \mathrm{~L} \text {; tiotropium, } \\
0.097 \text { and } 0.158 \mathrm{~L}) \text { versus placebo }\end{array}$ \\
\hline
\end{tabular}

Abbreviations: QD, once daily; BID, twice daily; $\mathrm{FEV}_{1}$, forced expiratory volume in I second; $\mathrm{AUC}_{0-3}$, area under the curve from 0 to 3 hours; PGR, Patient Global Rating; TDI, transition dyspnea index; SGRQ, St George's Respiratory Questionnaire; SMI, Soft Mist inhaler.

in FVC supported those observed for $\mathrm{FEV}_{1}$. Over 48 weeks, use of rescue medication was also significantly reduced and improvements in Patient Global Rating were maintained.

Two further replicate, Phase III, multicenter, randomized, double-blind, double-dummy, placebo-controlled, parallel-group pivotal studies evaluated the efficacy of once-daily treatment with olodaterol 5 and $10 \mu \mathrm{g}$ delivered via Respimat SMI (Boehringer Ingelheim Pharmaceuticals, Inc.) compared to placebo and formoterol $12 \mu \mathrm{g}$ twice daily in 1,838 patients with moderate to very severe COPD over 48 weeks. ${ }^{18}$ After 24 weeks, olodaterol significantly improved $\mathrm{FEV}_{1} \mathrm{AUC}_{0-3 \mathrm{~h}}$ and trough $\mathrm{FEV}_{1}$ versus placebo in both studies, 
as did formoterol. The efficacy of once-daily olodaterol 5 and $10 \mu \mathrm{g}$ was maintained over a 48 -week period. Improvements in lung function translated into symptomatic benefits in patients. St George's Respiratory Questionnaire (SGRQ) total score was significantly improved with olodaterol, but not formoterol, versus placebo.

Two other replicate, multicenter, randomized, doubleblind, double-dummy, placebo-controlled, four-way crossover studies evaluated the 24-hour $\mathrm{FEV}_{1}$ profile of olodaterol 5 and $10 \mu \mathrm{g}$ once daily compared to placebo and formoterol $12 \mu \mathrm{g}$ twice daily administered for 6 weeks in addition to usual-care background maintenance therapy in patients with moderate to very severe COPD. ${ }^{19}$ With both olodaterol doses, $\mathrm{FEV}_{1}$ increased to near-maximal 30 minutes postmorning dose, which was maintained over 24 hours. FEV 1 also increased within 30 minutes postmorning dose of formoterol, was comparable to both doses of olodaterol 0-3 hours postdose, and was maintained over 12 hours but was lower than the $\mathrm{FEV}_{1}$ responses observed with both doses of olodaterol 4-12 hours postdose. The second formoterol dose resulted in a further increase, sustained for an additional 12 hours. $\mathrm{FEV}_{1} \mathrm{AUC}_{0-12}$ and $\mathrm{AUC}_{12-24}$ responses with both once-daily olodaterol doses and twice-daily formoterol were significantly greater than placebo at 6 weeks. However, the adjusted mean $\mathrm{FEV}_{1} \mathrm{AUC}_{12-24}$ response for formoterol $12 \mu \mathrm{g}$ twice daily was significantly greater than olodaterol 5 and $10 \mu \mathrm{g}$ once daily. For both $\mathrm{FEV}_{1} \mathrm{AUC}_{0-12}$ and $\mathrm{AUC}_{12-24}$ responses, both doses of olodaterol were similar. No statistically significant differences in $\mathrm{FEV}_{1} \mathrm{AUC}_{0-24}$ responses were reported between all three active comparators. FVC responses mirrored the $\mathrm{FEV}_{1}$ results.

Two replicate studies were designed to evaluate the 24-hour $\mathrm{FEV}_{1}$ profile of olodaterol (5 and $10 \mu \mathrm{g}$ ) once daily (via the Respimat SMI, Boehringer Ingelheim Pharmaceuticals, Inc.) in comparison to placebo and to tiotropium once daily (via the HandiHaler, Boehringer Ingelheim Pharmaceuticals, Inc.) over 6 weeks in 230 patients with stable moderate to very severe COPD. ${ }^{20}$ The data confirmed the 24-hour lungfunction efficacy profile of olodaterol 5 and $10 \mu \mathrm{g}$ once-daily, with $\mathrm{FEV}_{1}$ responses over 24 hours that were comparable to tiotropium. $\mathrm{FEV}_{1}$ responses were comparable between olodaterol 5 and $10 \mu \mathrm{g}$ once-daily and support the selection of the $5 \mu \mathrm{g}$ dose for later use in clinical practice.

\section{Safety and tolerability}

A prespecified pooled safety analysis of olodaterol 5 and 10 $\mu \mathrm{g}$ from the large database of patients in the combined Phase III 48-week olodaterol studies, which formed the basis of the safety assessment for olodaterol registration, included 3,104 patients. ${ }^{21}$ Eight hundred and seventy six of them received olodaterol $5 \mu \mathrm{g}, 883$ received olodaterol $10 \mu \mathrm{g}, 885$ received placebos, and 460 received formoterol $12 \mu \mathrm{g}$ twice daily. Incidence of adverse events was generally balanced across groups. Also total serious adverse events were balanced across treatment groups. The most frequent adverse events were in the respiratory, thoracic, and mediastinal disorders categories, with a similar incidence across treatment groups. Cardiovascular adverse events, including major adverse cardiac events, were reported less frequently, with comparable incidences across groups. Numerically lower values were observed in the olodaterol-treated population.

\section{Place in therapy}

Nonadherence to medication plans is a major obstacle to successful management of COPD. ${ }^{22}$ Deplorably, adherence to COPD prescribed therapy is poor. ${ }^{23}$ In general, patients who are prescribed complex medication regimens or are exposed to frequent change of schedule may show episodes of unpredictable nonadherence. ${ }^{24}$ An important step in simplifying COPD treatment and improving adherence to prescribed therapy is that of dosing a medication at the lowest dose frequency necessary to maintain disease control. It has been suggested that the incorporation of once-daily dose administration might be an important strategy to improve adherence ${ }^{25}$ and, in any case it is a regimen preferred by most patients. ${ }^{26}$

In the literature, there is extensive documentation on the effectiveness of LABAs in the treatment of stable COPD. ${ }^{27}$ This is the main reason why the pharmaceutical industry has had, and still has, a strong interest to develop LABAs with improved duration of action over salmeterol and formoterol. This is not surprising because the documented role of LABAs in the treatment of stable COPD together with the obvious need for a dosing approach that may increase adherence to prescribed treatment indicates a clear medical requirement that, if satisfied, offers great market opportunities. ${ }^{28}$

Over the past decade, several newer $\beta_{2}$-agonists with longer pharmacodynamic half-lives have been discovered and called ultra-LABAs. ${ }^{29-31}$ Indacaterol is the archetype of this new group of $\beta_{2}$-agonists and is the first LABA approved for the treatment of COPD that allows for oncedaily administration. ${ }^{32}$ In addition to indacaterol, two other ultra-LABAs, vilanterol and olodaterol, have already been launched in several countries, although vilanterol is not currently approved for marketing as a monotherapy and is combined with umeclidinium, a LAMA, or fluticasone furoate, an inhaled corticosteroid.

Having entered into the market as the second, olodaterol should be compared with indacaterol. Regrettably, still 
there is no head-to-head comparison between these two ultra-LABAs. Nonetheless, an indirect treatment comparison by systematic review and synthesis of the available clinical evidence showed that olodaterol $5 \mu \mathrm{g}$ and indacaterol 75 or $150 \mu \mathrm{g}$ seemed to be equally effective in the treatment of patients with COPD, based on the analyses of change from baseline in trough $\mathrm{FEV}_{1}$, when compared under similar trial conditions. ${ }^{33}$ However, Donohue ${ }^{34}$ strongly criticized the findings of this systematic review because of missing data, the difference in the concomitant medication allowed between the trials of olodaterol and indacaterol, and the differences in COPD severity in the patient populations of the trials of the two LABAs. In any case, as highlighted by Chaplin, ${ }^{35}$ two fundamental characteristics differentiate olodaterol from indacaterol. Unlike indacaterol, olodaterol has only a single dose irrespective of COPD severity. Olodaterol is administered as a solution whereas indacaterol as a dry powder; the preference of patients for one inhaler over another can be crucial in deciding the drug to be prescribed, although a documented real difference in the clinical efficacy and/or safety profile is still lacking.

The clinical development of olodaterol is however still too partial to draw any firm conclusions on the positioning of this ultra-LABA as monotherapy in the management of COPD. In particular, we must highlight that large part of the development has been focused on lung function, ${ }^{36}$ although there is a signal, in truth not very strong, documenting a benefit in improving the HRQoL (SGRQ total score), but not dyspnea (Transition Dyspnea Index) with olodaterol compared to placebo. ${ }^{18}$ Moreover, there is only long-term (more than 12 weeks) comparison with formoterol, whereas long-term comparison with tiotropium or other LAMAs is still lacking.

Waiting for new data on the impact of olodaterol on different patient-reported outcomes, which however are widely available for indacaterol, and mainly for a head-to-head comparison between these two ultra-LABAs and between olodaterol and LAMAs, we believe it is correct to follow the clinical indications of indacaterol also for olodaterol. In our opinion, there is evidence that ultra-LABAs are more effective than LAMAs if we consider symptoms or HRQoL as the primary outcome. ${ }^{4,37}$ Moreover, in the symptomatic patient, ultra-LABAs should be preferred to LAMAs because of their rapid onset of action., ${ }^{4,37}$ In contrast, LAMAs appear to be more effective than ultra-LABAs if exacerbations are the expected primary outcome. ${ }^{4,37}$

Apparently, this can be valid if we focus only on the use of olodaterol as monotherapy. However, there is documentation that improvements in lung function induced by olodaterol translated into significant symptomatic benefits in patients with moderate to very severe COPD who continue to receive maintenance COPD therapy with tiotropium. ${ }^{18}$ Moreover, it has been documented that the 24-hour lung-function efficacy profile of olodaterol is comparable to that of tiotropium. ${ }^{20}$ The parallel bronchodilating modes of action of olodaterol and tiotropium make them an attractive combination in COPD. ${ }^{38}$

In effect, results from the ongoing large TOviTO Phase III trial program have documented the efficacy and safety of olodaterol/tiotropium fixed-dose combination as maintenance therapy in patients with moderate to very severe COPD. ${ }^{38}$ In particular, olodaterol/tiotropium fixed-dose combination provides a convincing alternative for patients remaining symptomatic on olodaterol monotherapy, as well documented by the results of the TONADO 1 and 2 trials. ${ }^{39}$

\section{Disclosure}

The authors report no conflicts of interest in this work.

\section{References}

1. Cazzola M, Page CP, Calzetta L, Matera MG. Pharmacology and therapeutics of bronchodilators. Pharmacol Rev. 2012;64:450-504.

2. Qaseem A, Wilt TJ, Weinberger SE, et al. Diagnosis and management of stable chronic obstructive pulmonary disease: a clinical practice guideline update from the American College of Physicians, American College of Chest Physicians, American Thoracic Society, and European Respiratory Society. Ann Intern Med. 2011;155:179-191.

3. Vestbo J, Hurd SS, Agustí AG, et al. Global strategy for the diagnosis, management, and prevention of chronic obstructive pulmonary disease: GOLD executive summary. Am J Respir Crit Care Med. 2013;187: 347-365.

4. National Clinical Guideline Centre. Pulmonary Disease: Management of Chronic Obstructive Pulmonary Disease in Adults in Primary and Secondary Care. London, UK: National Clinical Guideline Centre; 2010. Available from: http://guidance.nice.org.uk/CG101/Guidance/ pdf/English. Accessed August 31, 2015.

5. Cazzola M, Matera MG. Bronchodilators: current and future. Clin Chest Med. 2014;35:191-201.

6. Schwender CF, Sunday BR, Shavel Jr J. 3-[ $\alpha$-(tert-butylamino)methyl]5-hydroxy-m-xylene- $\alpha, \alpha^{\prime}$-diol, a selective bronchodilator. J Med Chem. 1974; 17:1112-1115.

7. Bouyssou T, Hoenke C, Rudolf K, et al. Discovery of olodaterol, a novel inhaled $\beta_{2}$-adrenoceptor agonist with a $24 \mathrm{~h}$ bronchodilatory efficacy. Bioorg Med Chem Lett. 2010;20:1410-1414.

8. Handley DA, Morley J. The pursuit of precision pharmaceuticals: divergent effects of $\beta 2$ agonist isomers. Expert Opin Investig Drugs. 1998;7:1601-1616.

9. Ramsay CM, Cowan J, Flannery E, et al. Bronchoprotective and bronchodilator effects of single doses of $(S)$-salbutamol, $(R)$-salbutamol and racemic salbutamol in patients with bronchial asthma. Eur J Clin Pharmacol. 1999;55:353-359.

10. Lötvall J, Palmqvist M, Ankerst J, et al. The effect of formoterol over $24 \mathrm{~h}$ in patients with asthma: the role of enantiomers. Pulm Pharmacol Ther. 2005;18:109-113.

11. Bouyssou T, Casarosa P, Naline E, et al. Pharmacological characterization of olodaterol, a novel inhaled $\beta_{2}$-adrenoceptor agonist exerting a 24-hour-long duration of action in preclinical models. J Pharmacol Exp Ther. 2010;334:53-62. 
12. Brown SM, Barnes PJ, Donnelly LE. Effect of olodaterol on the relaxation of small airways. Eur Respir J. 2011;38:308s.

13. Casarosa P, Kollak I, Kiechle T, et al. Functional and biochemical rationales for the 24-hour-long duration of action of olodaterol. J Pharmacol Exp Ther. 2011;337:600-609.

14. van Noord JA, Smeets JJ, Drenth BM, et al. 24-hour bronchodilation following a single dose of the novel $\beta_{2}$-agonist olodaterol in COPD. Pulm Pharmacol Ther. 2011;24:666-672.

15. Maleki-Yazdi MR, Beck E, Hamilton AL, et al. A randomised, placebo-controlled, Phase II, dose-ranging trial of once-daily treatment with olodaterol, a novel long-acting $\beta_{2}$-agonist, for 4 weeks in patients with chronic obstructive pulmonary disease. Respir Med. 2015; 109:596-605.

16. Joos GF, Aumann JL, Coeck C, et al. A randomised, double-blind, four-way, crossover trial comparing the 24-h $\mathrm{FEV}_{1}$ profile for oncedaily versus twice-daily treatment with olodaterol, a novel long-acting $\beta_{2}$-agonist, in patients with chronic obstructive pulmonary disease. Respir Med. 2015;109:606-615.

17. Ferguson GT, Feldman GJ, Hofbauer P, et al. Efficacy and safety of olodaterol once daily delivered via Respimat ${ }^{\mathbb{B}}$ in patients with GOLD 2-4 COPD: results from two replicate 48-week studies. Int J Chron Obstruct Pulmon Dis. 2014;9:629-645.

18. Koch A, Pizzichini E, Hamilton A, et al. Lung function efficacy and symptomatic benefit of olodaterol once daily delivered via Respimat ${ }^{R}$ versus placebo and formoterol twice daily in patients with GOLD 2-4 COPD: results from two replicate 48-week studies. Int J Chron Obstruct Pulmon Dis. 2014;9:697-714.

19. Feldman GJ, Bernstein JA, Hamilton A, et al. The 24-h FEV time profile of olodaterol once daily via Respimat ${ }^{\circledR}$ and formoterol twice daily via Aerolizer ${ }^{\circledR}$ in patients with GOLD 2-4 COPD: results from two 6-week crossover studies. Springerplus. 2014;3:419.

20. Lange P, Aumann J-L, Hamilton A, et al. The 24 hour lung function time profile of olodaterol once daily versus placebo and tiotropium in patients with moderate to very severe chronic obstructive pulmonary disease. J Pulm Respir Med. 2014;4:4.

21. Garvey L, Niewoehner D, Magder S, et al. One-year safety of olodaterol once daily via Respimat ${ }^{\mathbb{R}}$ in patients with GOLD 2-4 chronic obstructive pulmonary disease: results of a pre-specified pooled analysis. COPD. 2015;12:484-493.

22. Vestbo J, Anderson JA, Calverley PM, et al. Adherence to inhaled therapy, mortality and hospital admission in COPD. Thorax. 2009;64: 939-943.

23. Ágh T, Inotai A, Mészáros Á. Factors associated with medication adherence in patients with chronic obstructive pulmonary disease. Respiration. 2011;82:328-334.
24. Toy EL, Beaulieu NU, McHale JM, et al. Treatment of COPD: relationships between daily dosing frequency, adherence, resource use, and costs. Respir Med. 2011;105:435-441.

25. Cazzola M, Beeh KM, Price D, Roche N. Assessing the clinical value of fast onset and sustained duration of action of long-acting bronchodilators for COPD. Pulm Pharmacol Ther. 2015;31:68-78.

26. Price D, Lee AJ, Sims EJ, et al. Characteristics of patients preferring once-daily controller therapy for asthma and COPD: a retrospective cohort study. Prim Care Respir J. 2013;22:161-168.

27. Rossi A, Khirani S, Cazzola M. Long-acting $\beta_{2}$-agonists (LABA) in chronic obstructive pulmonary disease: efficacy and safety. Int J Chron Obstruct Pulmon Dis. 2008;3:521-529.

28. Cazzola M, Matera MG. Emerging inhaled bronchodilators: an update. Eur Respir J. 2009;34:757-769.

29. Cazzola M, Matera MG, Lötvall J. Ultra long-acting $\beta_{2}$-agonists in development for asthma and chronic obstructive pulmonary disease. Expert Opin Investig Drugs. 2005;14:775-783.

30. Cazzola M, Calzetta L, Matera MG. $\beta_{2}$-adrenoceptor agonists: current and future direction. Br J Pharmacol. 2011;163:4-17.

31. Cazzola M, Page CP, Rogliani P, Matera MG. $\beta_{2}$-agonist therapy in lung disease. Am J Respir Crit Care Med. 2013;187:690-696.

32. Matera MG, Rogliani P, Cazzola M. Indacaterol for the treatment of chronic obstructive pulmonary disease. Expert Opin Pharmacother. 2015;16:107-115.

33. Roskell NS, Anzueto A, Hamilton A, et al. Once-daily long-acting beta-agonists for chronic obstructive pulmonary disease: an indirect comparison of olodaterol and indacaterol. Int J Chron Obstruct Pulmon Dis. 2014;9:813-824.

34. Donohue JF. Systematic review comparing LABA, olodaterol, and indacaterol: limitations. Int J Chron Obstruct Pulmon Dis. 2014;9: 1331-1335.

35. Chaplin S. Striverdi Respimat: once daily LABA for COPD. Prescriber. 2015;26:25-26.

36. Deeks ED. Olodaterol: a review of its use in chronic obstructive pulmonary disease. Drugs. 2015;75:665-673.

37. Cazzola M, Page C. Long-acting bronchodilators in COPD: where are we now and where are we going? Breathe. 2014;10:110-120.

38. Cazzola M, Rogliani P, Ora J, Matera MG. Olodaterol + tiotropium bromide for the treatment of chronic obstructive pulmonary disease. Expert Rev Clin Pharmacol. 2015;8:529-539.

39. Buhl R, Maltais F, Abrahams R, et al. Tiotropium and olodaterol fixeddose combination versus mono-components in COPD (GOLD 2-4). Eur Respir J. 2015;45:969-979.
Therapeutics and Clinical Risk Management

\section{Publish your work in this journal}

Therapeutics and Clinical Risk Management is an international, peerreviewed journal of clinical therapeutics and risk management, focusing on concise rapid reporting of clinical studies in all therapeutic areas, outcomes, safety, and programs for the effective, safe, and sustained use of medicines. This journal is indexed on PubMed Central, CAS,

\section{Dovepress}

EMBase, Scopus and the Elsevier Bibliographic databases. The manuscript management system is completely online and includes a very quick and fair peer-review system, which is all easy to use. Visit $\mathrm{http}: / / \mathrm{www}$.dovepress.com/testimonials.php to read real quotes from published authors. 